\title{
Pharmacotherapeutic Study of Maharasona with Reference to Tamaka Shwasa
}

\author{
Research Article
}

\section{Sunila Hemant Deo ${ }^{1^{*}}$}

1. Professor and HOD, Department of Agadtantra,

D.Y. Patil College of Ayurveda and Research Center, D Y Patil University (Deemed to be), Pune.

\begin{abstract}
Tamaka Shwasa is considered to be a dreadful disease as it is yapya (hard to treat) and ashuprananashakari (destroys the life very fast) and has high prevalence in society and presents in vegas (attacks) and dyspnoea as its cardinal symptom. Ayurveda describes detailed line of treatment for Tamaka shwasa which includes shodhana, shamana, and brihana for apunarbhava. Shamana dravyas indicated in tamaka shwasa should be kaphavatashamaka, amapachana and anulomana. Maharasona is a dravya possessing katu madhur pradhan pancharasa, teekshna-ushna guna ushnaveerya, katuvipaka and vatakaphahara. Total 30 patients of Tamaka shwasa were selected as per inclusion criteria and treated with Maharasona (Allium porrum Lambinon et al.) Kalka 3 grams twice a day before meals with water. Incidence of agnimandya and kasa was observed very much associated with shwasa and kujanadhwani as its cardinal symptom. Maharasona kalka showed significant improvement in symptoms like shwasakruchrata, agnimandya, kaphanishtheevana, jwara and peenasa. This improvement may be due to its above said gunas. Hence, from this study, it can be concluded that Maharasona is effective and can be safely used in the management of Tamaka Shwasa.
\end{abstract}

Key Words: Maharasona, Grunjana, Allium porrum Lambinon et al., Tamaka Shwasa.

\section{Introduction}

Dravyagunshastra, an integral part of Ayurveda deals with the knowledge of the dravyas, its gunakarma and mode of its application and shows its glimpses in ashtangas of Ayurveda. Its proper use leads to health while improper use becomes the cause of disease.(1)

The history of dravyagunshastra can be traced back to the Vedic period. In Rugveda 67, in Yajurveda 81 and in Atharvaveda 289 dravyas are found to be mentioned of plant, animal and metal origin (2). Samhitas also show classification of dravyas in different aspects, but are mainly used on pharmacological properties. Drug descriptions are available with their pharmacology and therapeutics. Nighantus exhibit a still better, wide and detailed descriptions of dravyas, which are especially the texts on dravyaguna. In this, the morphology, synonyms, properties, pharmacological actions, therapeutics and accordingly the classification of individual drugs are available. Different properties and therapeutic indications described in Nighantus provides a wide area of research with single drugs in different diseases and in different views.

\section{* Corresponding Author:}

\section{Sunila Hemant Deo}

Professor and HOD, Department of Agadtantra,

D.Y. Patil College of Ayurveda and Research Center,

D Y Patil University (Deemed to be), Pune,

Maharashtra, India.

Email Id: shdeo2008@gmail.com
Descriptions about 'shwasa' are also found since the vedic period. 'Shwasa' - the normal respiration is the cause of existence of life (3). In the present context, the word 'shwasa' means - a disease pertaining to the impairment of normal breathing. Shwasa is considered to be a dreadful disease. Ayurveda describes shwasa as "Ashuprananashakari" (4) and its types among which Tamaka Shwasa is one. It is presented in attacks and prevalence is high. The prevalence is still going on increasing day by day due to the altered life style, faulty methods adopted in diet, stress and strain, increased urbanization and environmental pollution and under nutrition in the view of poverty prevailing all over the globe. The ailment is found all over the world in all socio - economic classes, geographical conditions, age, sex, profession, etc.

Breathlessness or dyspnoea is an unpleasant subjective awareness of sensation on breathing, and is a common symptom in cardiac and respiratory diseases. Asthma is defined as a disorder characterized by chronic airway inflammation and increased airway responsiveness resulting in symptoms as wheeze, cough, chest tightness and dyspnoea (5) (which very much is similar to Tamaka Shwasa).

Asthma is common and its prevalence is increasing. According to the global Asthma report 2018, it is a common chronic disease that is estimated to affect as many as 339 million people worldwide. It is a cause of substantial burden of disease, including both premature death and reduced quality of life in people of all ages in all parts of the world. Asthma contributes to be a major source of global economic burden in terms of both direct and indirect costs. In many countries, essential asthma medicines are unavailable, 
unaffordable or are of unreliable quality resulting in unnecessary burden and mortality from asthma. Patients die of asthma in low income countries from lack of effective management (6).

To save the mankind from this menace science is searching new and efficient drugs, which should be harmless to other systems of the body at the same time. The drug should be simple, beneficial and yet within the reach of common man. Hence the world is switching over and looking eagerly towards Ayurvedic system of medicine for the newer and safer drugs.

Ayurveda described a detailed line of treatment for Tamaka Shwasa in shodhana, shamana and brimhana for apunarbhavatwa aspects. Along with upakarmas for shodhana and different yogas; several shamakadravyas are also indicated. There is a need to render Ayurvedic system in this aspect to the present scientific world.

In the treatment of Tamaka Shwasa the shamanadravyas which can be used should be kaphavatashamaka, amapachana and anulomana (7) so that it can act over the dushtakapha (circulating along with vruddharasa) and getting enlodged in prana vaha strotas causing vimargagamana and prakopa of vata and contributing for the samprapti.

'Maharasona' as described in classics is a dravya possessing katu - madhura pradhana pancharasa, teekshna - ushna guna, ushna veerya and katuvipaka and vatakaphaharatwa. All these gunas will help in samprapti vighatana of Tamaka Shwasa and by its gandhapradhyana it will have its affinity for pranavaha strotas, thus relieving the signs and symptoms.

But Maharasona otherwise also called Grunjana is a controversial drug (8). Therefore, botanical identification and confirmation of the species was done, so that the gunakarmas of Maharasona as described in the texts can be verified with the confirmed species, which is Allium Porrum.

The aim of the present study is to highlight the efficacy of Maharasona in Tamaka Shwasa. Tamaka Shwasa, through yapya, needs attention in management on account of agony and distress caused to the patient. This can be achieved by subjecting the time - tested effective drugs mentioned by granthakaras. Here a humble effort is made to find out significance of Maharasona in Tamaka Shwasa chikitsa clinically.

Before proper clinical trials, authenticity and quality of drug is assured by botanical identification and conformation and chromatography (HPLC method).

\section{Aims and Objectives}

Aim:

- To study the efficacy of Maharasona (Allium porrum) in Tamaka Shwasa.

\section{Objectives:}

- To assess the gunakarmas of Maharasona as described in texts clinically.

- To assess efficacy of Maharasona in Tamaka Shwasa.

\section{Materials and Methods}

Patients

\section{Selection Criteria}

30 cases of Tamaka Shwasa were selected from Out Patient Department at random.

\section{Inclusion Criteria}

Known bronchial asthma cases with repeated episode, bronchitis.

\section{Exclusion Criteria}

Patients diagnosed with anaemia, pulmonary tuberculosis, cardiac asthma, tropical eosinophilia, COPD, etc were not included.

\section{Examination of Patients}

Detailed history of patients related to the disease was taken and thorough clinical examination was done and recorded on a specially prepared case sheet for this assessment.

Among objective parameters the laboratory investigations like CBP and ESR, complete urine examination was taken.

\section{$\mathrm{X}$-ray PA chest was done.}

\section{Drug Regimen}

The bulbs of Maharasona were given to patients and advised to prepare fresh paste. Three grams paste was adviced twice a day.

\section{Anupana}

Cold water/lukewarm water. In a few cases of Pittaprakruti, sugar water or milk.

\section{Pathya}

Adviced to take light vegetarian foods like Jowar Roti, Green Gram, all vegetables and advised to take evening meals early (around 7:00-7:30 PM).

\section{Apathya}

Guru-abhishyandi ahar (Food that is heavy to digest), dadhisevana (Consumption of curd), spicy nonveg food, late night food, adhyashana (overeating) and vishamashana (eating food irrelevant to appetite) were told to be prohibited.

\section{Assessments of Results}

The subjective and objective parameters and its data have been recorded and its results were assessed statistically.

\section{Observations}

Observations while doing clinical evaluation regarding disease and changes in symptoms after administration of the research drug as a result of effect of drug were noted. The patients who had undergone clinical trials were subjected for classification in different aspects and its statistical analysis was done. 
Table 1: Classification according to the sex of the patients

\begin{tabular}{|c|c|c|c|}
\hline Serial Number & Sex & Number of patients & Percentage \\
\hline 1 & Male & 17 & $56.66 \%$ \\
\hline 2 & Female & 13 & $43.33 \%$ \\
\hline & Total & 30 & $100 \%$ \\
\hline
\end{tabular}

Table 2: Classification according to the age group of the patients

\begin{tabular}{|c|c|c|c|c|c|c|}
\hline $\begin{array}{c}\text { Serial } \\
\text { Number }\end{array}$ & Age Group & $\begin{array}{c}\text { Number of } \\
\text { male patients }\end{array}$ & \% Age & $\begin{array}{c}\text { Number of } \\
\text { female } \\
\text { patients }\end{array}$ & \% Age & $\begin{array}{c}\text { Total } \\
\text { Percentage }\end{array}$ \\
\hline 1 & $01-20$ Years & 3 & $10.00 \%$ & 2 & $6.66 \%$ & $16.66 \%$ \\
\hline 2 & $21-40$ Years & 7 & $23.33 \%$ & 7 & $23.33 \%$ & $46.66 \%$ \\
\hline 3 & $41-60$ Years & 5 & $16.66 \%$ & 4 & $13.33 \%$ & $30.00 \%$ \\
\hline 4 & 61-80 Years & 2 & $6.66 \%$ & 0 & - & $6.66 \%$ \\
\hline & Total & 17 & $56.66 \%$ & 13 & $43.33 \%$ & $100.00 \%$ \\
\hline
\end{tabular}

Table 3: Distribution according to the place of residence of the patients

\begin{tabular}{|c|l|c|c|}
\hline Serial Number & \multicolumn{1}{|c|}{ Area } & Number of Patients & Percentage \\
\hline 1 & Urban & 20 & $66.66 \%$ \\
\hline 2 & Suburban & 6 & $20.00 \%$ \\
\hline 3 & Rural & 4 & $13.33 \%$ \\
\hline & Total & 30 & $100.00 \%$ \\
\hline
\end{tabular}

Table 4: Distribution of patients based on socio-economic status

\begin{tabular}{|c|c|c|c|}
\hline Serial Number & Socio-Economic Status & Number of patients & Percentage \\
\hline 1 & Rich & 3 & $10 \%$ \\
\hline 2 & Middle & 12 & $40 \%$ \\
\hline 3 & Poor & 15 & $50 \%$ \\
\hline & Total & 30 & $100 \%$ \\
\hline
\end{tabular}

Table 5: Distribution of patients based on occupation

\begin{tabular}{|c|l|c|c|}
\hline Serial Number & Class & Number of patients & Percentage \\
\hline 1 & Laborious & 11 & $36.66 \%$ \\
\hline 2 & Average & 13 & $43.33 \%$ \\
\hline 3 & Sedentary & 6 & $20.00 \%$ \\
\hline & Total & 30 & $100 \%$ \\
\hline
\end{tabular}

Table 6: Distribution of patients of Tamaka Shwasa based on their dietary habits

Serial Number

1

Type of Diet

Vegetarian

Non-Vegetarian

Total
Number of patients

12
18
30

Percentage
$40 \%$
$60 \%$
$100 \%$

Table 7: Distribution of patients of Tamaka Shwasa based on prevalence of Heredity Origin

Serial Number

1

1

Serial Number

\begin{tabular}{|c|l|c|c|}
\hline Serial Number & Duration in Years & Number of Patients & Percentage \\
\hline 1 & $1-3$ Years & 12 & $40.00 \%$ \\
\hline 2 & 3-6 Years & 14 & $46.66 \%$ \\
\hline 3 & 6 Years and Above & 4 & $13.33 \%$ \\
\hline & Total & 30 & $100 \%$ \\
\hline
\end{tabular}

\section{Heredity Origin}

Present

Absent

Total
Number of Patients

7
23
30

23

Percentage

$23.33 \%$

$76.66 \%$

$100 \%$

Table 8: Distribution of patients based on Chronicity of illness

Incidence of Symptoms found in patients

Based on subjective parameters, the incidence of different symptoms of Tamaka Shwasa found in patients having Shwasa Kruchrata as a main symptom in all patients (100\%) is as follows: 
Table 9: Table Showing Incidence of Symptoms before Treatment

\begin{tabular}{|c|l|c|c|c|}
\hline Serial Number & Symptoms & Total Patients & $\begin{array}{c}\text { Number of patients } \\
\text { with symptoms } \\
\text { present }\end{array}$ & Percentage \\
\hline 1 & Shwasakruchrata & 30 & 30 & $100.00 \%$ \\
\hline 2 & Kasa & 30 & 27 & $90.00 \%$ \\
\hline 3 & Peenasa & 30 & 20 & $66.66 \%$ \\
\hline 4 & Kunjanadhwani & 30 & 28 & $93.33 \%$ \\
\hline 5 & Shtheevana & 30 & 18 & $60.00 \%$ \\
\hline 6 & Agnimandya & 30 & 28 & $93.33 \%$ \\
\hline 8 & Vibandha & 30 & 22 & $73.33 \%$ \\
\hline 9 & Anidra & 30 & 13 & $43.33 \%$ \\
\hline 10 & Jwara & 30 & 4 & $13.33 \%$ \\
\hline
\end{tabular}

While going for the objective parameters the eosinophils were found to be raised in 11 patients.

Table 10: Distribution According to Eosinophil count in the Patients

\begin{tabular}{|c|l|c|c|}
\hline Serial Number & Eosinophil Count & Number of Patients & Percentage \\
\hline 1 & Normal Range & 19 & $63.33 \%$ \\
\hline 2 & Raised Count & 11 & $36.66 \%$ \\
\hline & Total & 30 & $100.00 \%$ \\
\hline
\end{tabular}

\section{Results after Drug Trials}

Results were assessed based upon the subjective parameters i.e, signs and symptoms assessed clinically and objective parameters - Eosinophil count mainly taken into consideration. Follow-up examination was done repeatedly during 15 days course of administration and the changes were noted weekly, i.e on the $8^{\text {th }}$ and $15^{\text {th }}$ day.

Table 11: Table showing the Recovery of Symptoms in patients of Tamaka Shwasa after Administration of Maharasona

\begin{tabular}{|c|c|c|c|c|c|}
\hline Serial Number & Symptoms & $\begin{array}{c}\text { No. of } \\
\text { patients B.T. }\end{array}$ & \multicolumn{2}{c|}{$\begin{array}{c}\text { No. of Patients relieved A.T. } \\
\mathbf{8}^{\text {th }} \mathbf{d a y}\end{array}$} & $\begin{array}{c}\text { \%o of Recovery } \\
\text { (compared to BT) }\end{array}$ \\
\hline 1 & Shwasakruchrata & 30 & 6 & 22 & $73.33 \%$ \\
\hline 2 & Kasa & 27 & 14 & 25 & $92.50 \%$ \\
\hline 3 & Peenasa & 20 & 4 & 18 & $90.00 \%$ \\
\hline 4 & Kunjanadhwani & 28 & 10 & 21 & $75.00 \%$ \\
\hline 5 & Shtheevana & 18 & 4 & 13 & $72.15 \%$ \\
\hline 7 & Agnimandya & 28 & 16 & 28 & $100.00 \%$ \\
\hline 8 & Vibandha & 22 & 14 & 9 & $50.80 \%$ \\
\hline 9 & Anidra & 13 & 3 & 7 & $75.03 \%$ \\
\hline 10 & Jwara & 4 & 2 & 3 & $80.00 \%$ \\
\hline
\end{tabular}

Recovery in the raised Eosinophil Count was also recorded (Table 12).

Table 12: Table Showing the Distribution of Recovery in the raised Eosinophil count

\begin{tabular}{|c|c|c|c|c|}
\hline \multirow{2}{*}{ Eosinophils Count Raised } & \multirow{2}{*}{ Before Treatment } & \multicolumn{2}{|c|}{ After Treatment } & \multirow{2}{*}{ Not Reported } \\
\hline & & Relieved & Not Relieved & \\
\hline Number of Patients & 11 & 7 & 3 & 1 \\
\hline Percentage & $100.00 \%$ & $63.63 \%$ & $27.27 \%$ & $9.09 \%$ \\
\hline
\end{tabular}

\section{Discussion}

The significance of undertaking this study could be very well justified by proving the efficacy of gunakarmas by having clinical trials and highlighting the dravyas which are efficient but used less in practice.

The present study is an outcome for the above said significance, conducted with the four - fold manner (naamroopa, gunakarma, prayoga and aushadhividnyam); and dealing about Maharasona to assess its gunakarmas practically, especially pertaining to its effective utility in management of Tamaka Shwasa.

Tamaka Shwasa or otherwise diagnosed as Bronchial asthma is the common disease, affecting millions of the population and this prevalence is going on increasing. It is identified as an important problem and though yapya (9), detailed description about its chikitsa aspects is found in samhitas.

A person suffering from Tamaka Shwasa is generally having daurbalya of pranavaha strotas (weak respiratory system) and the sthana samshraya of 
doshas mainly occurs in the functioning structures of fuffusa (lung). The symptoms are caused because of avritatwa i.e. blockage and vimargagamana of vata due to the sanga of kapha in the urasthana i.e. airways in the lungs (mainly the bronchus - bronchioles). Because of this the prana and apana gati of the vayu are disturbed causing shwasakashtata. The kapha which is mala of rasadhatu becomes dushta due to dhatu dushti and rasadhatvagnimandya. Also, kaphavruddhi is there in amashya (it's udbhavasthana) when prathama avasthapak vikriti is their which is as the result of agnimandya (10)(11).

Because of this agnimandya, pravruddha kapha, vimargaga vata and rasavaha, annavaha and pranavaha srotodushti lakshanas like shwasa kruchrata, kasa, kapha nishtheevana, jwara, aruchi, vibandha, etc are seen. In complete vegavastha or vyaktavastha i.e. when hetu, dosha and dushya are with sampoorna bala, asinau labhate saukhyam, sheero gaurava, timiradarshana, trushna, kasate pramoham, lalate swedana, vepathu, etc lakshanas are also seen (12).

Demographic records of the clinical work show that shwasakruchrata - the cardinal symptoms were found in all patients and on examination kunjandhwani was found in most of the patients (28 out of 30). Agnimandya which is a cause as well as symptom found, is having prevalence in $94 \%$ of people. Kasa is also a major presenting symptom in attack stage which most of the patients complained about, only $10 \%$ of the patients did not present vyaktavastha of this symptom. The prevalence of Tamaka Shwasa is more in males and in the age group of $21-40$ years.

It is found that the prevalence is more from the people residing in urban area, revealing the fact that the disease is more in densely populated and polluted areas. Poor socio - economic status and exertional work is found to be in greater percentage in the patients suffering from this disease.

Majority of the people consuming non vegetarian diet was comparatively more. In other hetus patients were found to be consuming more vidagdha ahara, amlarasa and abhishyandi food and late -night meals which explains the karya karana mimansa of agnimandya and vibandha and more possibility of amasanchaya.

It was seen that patients responded less in cold and rainy climate to the medicine as these are the aggravating factors for the disease.

Patients having tendency to develop the disease with the family history, i.e. by heredity also showed relatively very less or temporary response to the drug than expected.

In the objective parameters taken into consideration, Differential Leucocyte Count, mainly the eosinophils were found to be increased only in 11 patients, out of which more than $2 / 3^{\text {rd }}$ showed a marked reduction and $1 / 3^{\text {rd }}$ didn't respond as expected.

Granthakaras explain a clear and detailed line of treatment for vegavastha and avegavastha also in shodhana, shamana and apponarbhava chikitsa aspects. For this many kalpas and yogas are described in the texts. Different ganas are also described where single drugs are noted for the treatment.

Maharasona or Grunjana has not been mentioned under shwasahara dashemani of Charaka, but has been mentioned in shwasa chikistadhyaya (13). Acharyas and Nighantukaras have mentioned it to be kapha vyadhihara and more specifically can be used in the treatment of shwasa.

Grunjana is said to have pradhana katu and madhurarasa, katu vipaka, ushna veerya, ushna and teekshna gunas and grahi, vata - kaphahara and pittavardhana karmas (14)(15)(16)(17)(18).

Agnimandya was relieved because of katu rasa, katu vipaka, ushnatwa and pittavardhana properties of the drug after administering it. Kaphaprakopa was reduced by its teekshna ushna guna, katu vipaka and katu rasa. While alpamadhura rasa and ushnatwa are responsible for anulomana and vimargaga and avruddha vayu especially in lungs because the drug is having its route of excretion through this way also along with skin and kidney.

When kaphavilayana, shamana and vatanulomana occurred as a result of action of drug, symptomatic relief was seen especially about the lakshanas like shwasakruchrata, agnimandya, kapha nishtheevana were relieved. Kasa also reduced and jwara which was found in few patients was also reduced.

When the need of pachana was over and still the drug was continued to be consumed, grahi action of the drug was found. This may be because even though the drug is deepana pachana it is having less concentration of volatile oils resulting in rukshatwa comparatively. The vibandha of sama mala which appeared to be relieved after its pachana was again seen in few cases in niramawastha.

With the ushna - teekshna guna, srotovivarana and kaphavilanya occurred hence making it mucolytic and thus helping in easy nistheevana.

In toto agnimandya was relieved by ushna teekshna guna and deepana - pachana karma of Grunjana. Jwara and peensa were also relieved after pachana.

Shwasakruchrata, kasa, shtheevana were relieved after kapha - vatanuloma and kaphanashana caused by the properties of the drug.

As the symptoms were relieved, patients reported of better sleep.

Only alpamaladharana (vibandha) was seen in few patients after pachana stage due to the grahi guna of the drug.

Few patients reported of urovidhaha, netradaha and mutradaha. These symptoms were seen specifically in pittaprakruti individuals or in balyavastha.

The above said effects caused by the drug can be neutralized if the drug is given with changing the anupana or the form of the drug. Some patients were advised to take sugar water or children were advised to take with milk.

But the drug was given in fresh kalka form orally with water so that the gunakarmas of the drug and its action over the body can be assessed correctly. 
Kalka was to be prepared as in this form the active principles of the drug are found to have some chemical changes and give better effect.

The quantity of drug was given 3 grams, twice a day. The quantity of kalka was indicated to be one karsha (12 grams) as a dose, but because of teekshnatwa the quantity was reduced making a range of 6 grams per day.

After going through all the details and assessment, statistically the readings were compared before and after treatment, which shows that Maharasona (Allium Porrum) is highly significant in Tamaka shwasa.

\section{Conclusion}

Maharasona given in kalka form was able to significantly relieve the symptoms in vegavastha of Tamaka Shwasa.

The subjective paramaters shwasakruchrata, kasa, peenasa, agnimandya, kunjandhwani, jwara, anidra, kapha shtheevana, were found to be reduced after 15 days of treatment by $73.33 \%, 92.5 \%, 90 \%$, $100 \%, 75 \%, 100 \%, 53 \%, 72.15 \%$, respectively.

Maharasona is also able to show a marked reduction in eosinophil count by $63.63 \%$.

\section{Further Scope}

This is the preliminary clinical study carried out in limited number of patients. An elaborate study is needed on more patients of Tamaka shwasa based on different parameters. Further studies are required over the drug, to determine its activity and its mode of action on the different systems of the body, and that of the drug as a whole and its active principles, in various conditions indicated by the acharyas.

The drug can be given in ksheerapaka form so as to reduce its teekshnatwa and dhahkaratwa. Grahi property may also reduce if the drug is given in this form. Sharangdhara has described ksheerpaka Kalpana of rasona which can be practically applied while administering this drug also, so that the above said effects can be reduced.

\section{References}

1. Acharya Yadavji Trikamji's Charaka Samhita with Ayurvedadipika Commentary by Chakrapani, Sutrasthan 1/124-126. Varanasi; Chaukhamba Surbharti Prakashan; 1992. 23p.

2. Acharya Priyavrat Sharma's Ayurved Ka Vaidnyanik Ithihaas. 2014 Reprint. Varanasi; Chaukhamba Orientalia; 2014. 43p.

3. Chintaman Shastri Thatte's Edition (of 1882) commentary of Mahesvara on Amarsingh's Amarkosh 1/64. Mumbai; Govt. Central Book Depot; 1896. 13p.
4. Acharya Yadavji Trikamji's Charaka Samhita with Ayurvedadipika Commentary by Chakrapani, Chitkitsasthan 17/6. Varanasi; Chaukhamba Surbharti Prakashan; 1992. 533p.

5. Davidson's Principle and Practice of Medicine. Edition 19th. Edinburgh; Elsevier Science Ltd; 2002. 494,495,513p.

6. http://globalasthmareport.org dated 04-11-2020 time 11:04 IST.

7. Acharya Yadavji Trikamji's Charaka Samhita with Ayurvedadipika Commentary by Chakrapani, Chitkitsasthan 17/74-76. Varanasi; Chaukhamba Surbharti Prakashan; 1992. 536p.

8. Acharya Bapalal G. Vaidya Some Controvertial Drugs in Indian Medicine. Edition 1. Varanasi; Chaukhamba Orienatlia; 1982. 93 -97p.

9. Acharya Yadavji Trikamji Charaka Samhita with Ayurvedadipika Commentary by Chakrapani, Chitkitsasthan 17/62. Varanasi; Chaukhamba Surbharti Prakashan; 1992. 535p.

10. Harishastri Paradkar Vaidya Sarvangsundara of Arundatta and Ayurvedrasayana of Hemadri commentary of Ashtang Hridaya, Chikitsasthan 4/3,4. Varanasi; Chaukhamba Sanskrit series office; 1982. 603p.

11. Acharya Yadavji Trikamji and Achyara Narayan Ram Nibandh Samagraha Commentary of Dalhanacharya on Sushrut Samhita, Uttarasthana 51/4,8-10. Edition 5. Varanasi; Chaukhamba Orientalia; 1992. 761, 762p.

12. Acharya Yadavji Trikamji Charaka Samhita with Ayurvedadipika Commentary by Chakrapani, Chitkitsasthan 17/55-64. Varanasi; Chaukhamba Surbharti Prakashan; 1992. 535p.

13. Acharya Yadavji Trikamji Charaka Samhita with Ayurvedadipika Commentary by Chakrapani, Chitkitsasthan 17/131. Varanasi; Chaukhamba Surbharti Prakashan; 1992. 537p.

14. Acharya P.V. Sharma and Guruprasad Sharma's Commentary on Kaiyadeva Nighantu 1/1225-1226. Edition 1. Varanasi; Chaukhamba Orientalia Series; 1979. 226p.

15. Sharma P.V. and Guruprasad Sharma Dhanvantari Nighantu 4/63. Varanasi; Chaukhamba Orientalia Series; 2008. 132p.

16. Panchanan Pandit Ramprasad Vaidyopadhyay's Madanpalakrut Madanpala Nighantu 7/78. Mumbai; Khemraj Krishnadas Prakashan; 1998. 154p.

17. Dwivedi R.R. and Gyanedra Pandey's commentary on Shodhala's Shodhala Nighantu 4/423. Edition 1. Varanasi; Chaukhamba Krishnadas Academy; 2009. 98p.

18. Indradev Tripathi's commentary on Pandit Narhari's Raj Nighantu 7/53,54. Varanasi; Chaukhamba Krishnadas Academy; 2003. 198p. 